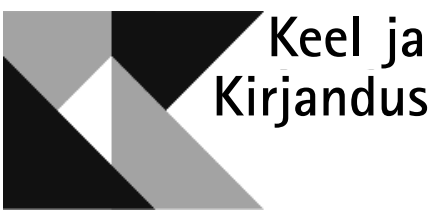

\title{
HILISE AAVIKU RADIKAALNE KEELEUUENDUS
}

\author{
MATI HINT
}

\section{"Ideepe"1}

$\mathrm{J}$ ohannes Aaviku sõjaaegne isiklik päevik (31. jaanuarist 1942 kuni 1. detsembrini 1943), mis üllitati tema 130. sünniaastapäevaks (8. XII 2010), muudab kindlasti järelpõlve pilti Aaviku isiksusest ning tema keeleuuendusest. „Ideepe” (< idee + päevik) pidi Aaviku kavatsuse järgi esitama „kogu Keeleuuenduse filosoofia ja ideoloogia...." (6972). Koos Aaviku isiksuse detailvaadetega näitab päevaraamat ka radikaalset keeleuuendust uudses rakenduslikus valguses, sest päeviku keel on keeleuuenduslik.

Keeleuuendusest on eesti avalikkuses kõneldud-kirjutatud palju üldsõnalist pateetikat. Radikaalse lõpmatuseni ulatuva keeleuuenduse hukatuslikkust pole teoreetiliselt kuigi põhjalikult analüüsitud (Valter Tauli ütleb siiski mõndagi, kuid tal polnud lugeda „Ideepet”, vt Tauli 1982a; 1982b). „Ideepe” kirjutamise ajal üle 60-aastase Aaviku keeleuuendus on ta varasematest programmidest veelgi ründavam, seetõttu on selle teoreetiline analüüs vajalik.

"Ideepe" käsitlus on jagatud kolme ossa: 1. Hilise Aaviku radikaalne keeleuuendus. 2. Aaviku isiksus „Ideepes”. 3. Aaviku esteetilised vaated. Kaks viimast alajaotust ilmuvad loodetavasti Loomingus. Need käsitlevad Aaviku

\footnotetext{
1 „Ideepe.” Johannes Aaviku ideede päevik. Väljaande koostaja ja peatoimetaja Helgi Vihma. Keele- ja tehniline toimetaja, registrite koostaja Aili Norberg. Johannes Aaviku Selts \& TEA Kirjastus, 2010. XI + 740 lk. Väljaande valmimist on toetanud Vabariigi Presidendi Kultuurirahastu, Eesti Kultuurkapital, Eesti Kultuuriseltside Ühendus, Nõmme Linnaosa Valitsus.

2 Siin ja edaspidi esitatakse sulgudes „Ideepe” leheküljed.
} 
töid, tegemisi ja olmet sõja ajal, tema poliitilisi vaateid ja hinnanguid Eesti oludele, eesti intelligentsile ja kolleegidele, sõja käigule, Eesti tulevikule, aga ka Aaviku vaateid kirjandusele ja kirjanikele, kunstile ja kunstnikele, poliitikale ja poliitikutele jpm. Kuid muidugi kuuluvad kõik teemad kokku. Ka keeleuuenduse äärmuslik arendus leiab seletuse Aaviku isiksuses.

Järgnev analüüs on „Ideepe”-järgne täiendus autori ettekandele 20. novembril 2010 Johannes Aaviku Seltsi ja Tallinna Teadlaste Maja korraldatud konverentsil, mis oli pühendatud Aaviku 130. sünniaastapäevale. Tolles ettekandes „Kas ynned sa olbama sirnangot? Johannes Aaviku visionäärsus keeleteoreetilisest vaatepunktist” (Hint 2011) oli Aaviku keeleuuenduse hindamisel võimalik lähtuda üksnes „Ideepe”-eelsest kontekstist. „Ideepe” muudab oluliselt nii keeleuuenduse kui ka Aaviku isiksuse konteksti omas ajas.

\section{Keeleuuenduse teoreetiline alus}

Keeleuuenduse teoreetilise aluse esitab Aavik „Ideepe” viimasel leheküljel: „Igas Euroopa kultuurkeeles leidub sõno, mindele eestikeeles ei ole häid ja täpseid vasteid. Tähtsamaist kultuurkeelist, mindest eestikeele kõige rohkem tõlgitakse, tuleks noppida ja teha sellaste sõnade list ja siis hakata katsoma neile luua eestikõlalisi vasteid" (698). Keeleuuenduse käivitanud mõttekäik oli ja on teatava piirini produktiivne. Kuid põhimõttena on see väär: ei saa koondada ühte keelde kõigi tähtsamate kultuurkeelte sõnade erinevate tähendusvarjundite väljendamiseks vajaminevat sõnavara. Samasugune mõte on Aavikul olnud grammatikas: talle tuntud võõrkeelte grammatiliste tähenduste väljendamise võimalustele on ta püüdnud kunstlikult luua vasteid uuenduslikus eesti keeles. Eeskujuks on ladina, prantsuse, vene, vähemal määral soome ja saksa keel. Ent ühte keelde ei ole võimalik koondada mitme keele grammatikaid.

Aavik vaatas eesti keelele väljastpoolt, läbi teiste keelte prisma. Eesti keele erinevused ja omapära muutuvad niisuguses vaates puudusteks, mida tuleb hakata parandama. Eesti mentaliteedis on kinnistunud kõige võõra paremakspidamine ning ka keeleuuenduses avaldub see selgelt. Igas keeles leidub parandamist vajavat, aga keeleideoloogiana on keele ümbertegemine võõraste mallide järgi põhimõtteliselt vale.

Arvutitõlke teoorias on tuntud sellelaadne mõttekäik: koondada arvuti metagrammatikasse mitme omavahel tõlgitava keele grammatikad, nii et programmis osalevate keelte vormide grammatilised tähendused analüüsitakse elementaarsemateks komponenttähendusteks ning tõlkimisel leitakse lähtekeele iga sellise komplekti vasteks sihtkeeles võimalikult sobiv grammatiliste elementaartähenduste komplekt. Aga selline metagrammatika ei ole ühe keele grammatika, vaid konstrukt. Aavik oleks kõik ahminud uuendusliku eesti keele grammatikasse (nagu ka sõnavarasse).

"Ideepe" keeletarvitus annab varasemast selgema ettekujutuse Aaviku enda keelest, sest siin oli ta vaba ametliku keele ja korrektorite survest: „... ei tarvitse ma selles keele suhtes nõõvata yhtki tagasihoiet. Kõik keeleuuenduse registrid lahti!" (6). Uuenduslikul keelel on tõesti teatav võlu. Seda keelt harjub lugema, kuigi kunagi ei tea, missugune uuendus järgmises lauses ees ootab. Küsimus on: kui kaugele võib minna, et piirideta keeleuuendus ei oleks ohuks keelelisele järjepidevusele. Aavik ise ütleb: „Keele pidevuse katkemise- 
ga katkeb ka rahvuse olemasolu pidevus, rahvus sureb, teissugust keelt rääkiv rahvas on ka teine rahvus" (521). See on nii ja ometi päris pole ka. Lõunaeesti keel on kunagisel ulatuslikul lõunaeesti keelealal asendunud/asendumas põhjaeestilise kirja- ja kõnekeelega. Rahvast see teiseks ei muuda, kuigi identsuse oluline komponent teiseneb.

Aavik laitis kõnekeele hälbeid kirjakeelest ja murdekeelsusi kirjakeeles (513-523). Ta esindas põlvkonda, kelle ideaaliks oli üks ühtne kirjakeel kogu maal, Aavikul muidugi uuenduslik eesti keel. See põlvkond kasvatas veel 1960-ndateni Tartu ülikoolis eesti keele õpetajaid, kes pidid valvama, et õpilased vahetunni ajal murdekeelt ei kõneleks. Õnneks sai see aeg läbi, suhtumine kohalikku keeleidentiteeti on otsustavalt liberaliseerunud. Aavikule oleks igatahes Võru murde keeleks kuulutamine ja Võru keeleidentsus olnud šokk.

„Ideepe” teemade registris leidub omaette märksõna lõuna-eesti keele vaesus (702). Vaen lõunaeesti keele vastu (187, 343, 349, 426, 518-520, 617) ulatub naeruväärsuseni, kui Aavik süüdistab tartu keelt selles, et küsisõna kas? võtab maad: „Tõhusam ja peenem aga on ytelda: ons ta sääl?” (519). Ta ise kasutab küsisõna kas? tõesti harva, aga siiski: „Kas peaks niisuguseid veel kuskilt saada olema?" (95).

Eesti üldküsimuse sõna $k a s ?$ on lihtne ja are küsimuse vormistamise vahend, üldtüpoloogiliseltki tõeliselt suurepärane eesti keele eriline võimalus. Aaviku soovitatud Ons ta sääl? on küll võimalik, aga Tulebs ta sinna? või Lähebs ta sä̈̈lt? ehk mitte, Armastabs ta mind? hoopiski mitte.

\section{Aavik ja ametlik keel}

Pidevalt hõõgvel hoitavas vihas niinimetatud ametliku keele vastu on Aavik loonud terve Elmar Muuki ja Johannes Voldemar Veskit halvustava sõnapere: muukveskismid, korrektorismid, rõivakeel, rõivakeelsus, rõivakeelitsema; ametliku keele kasutajad on rõivistid ehk rõivakeellased (Aavik ei sallinud lõunaeestipärasusi sõnavaras).

„Ideepe” lehekülgedelt võiks kokku lugeda vist sadu muukismide, veskismide, muukveskismide $(5,31,228,232-233,333,442,485,501 \mathrm{jm})$ ja rõivakeele $(29,31,41,42,118,225,227-228,232-233,237,258,259,265,287,329$, $330,333,338,345,441,442,492,496,498,499,501,523,565$ jm) ning rõivismide $(31,41,141,485,523,622 \mathrm{jm})$ vastast avaldust.

„Ei rõivakeelega saa Eesti rahval olema õnne! Ainolt uuendet keel velvib parema tuleviko! Maha rõivakeel! Puhastet ja uuendet eestikeel hõirigo!” (523).

Tolleaegse Eesti keeleteadlasi ja keeletegelasi peab ta peaaegu eranditult enda vaenlasteks. Vaenlaste nimekirjas on Andrus Saareste, Elmar Muuk, Aleksander Vaigla, Jaan Ainelo, J. V. Veski, Lauri Kettunen (41-42). Veski ja Muugi kõrval peab ta oma eriliseks vastaseks Andrus Saarestet (174). Elmar Elisto on Aavikule pedantne rõivist ja veskist (442). Saarestest ja Veskist arvas Aavik, et need „suhtuvad uute sõnade loomise ideele kadeduse pärast neenivalt [ignoreerivalt]" (34). Ka kirjastuste korrektorid Roos, Nurkse, Pürkop (trükitud tekstis Piiskop - ilmne mahakirjutamisviga), Veski ja hirmus Juhan Libe olid Aaviku silmis tema isiklikud vastased (17). 
Ei jäägi Aavikul muud üle, kui hakata ootama, millal surevad või saavad tudideks Andrus Saareste, Valter Tauli, Rein Nurkse, Eduard Roos, Ernst Nurm, Helmut Pürkop - Aavikust nooremad mehed (499).

Isiksuste võrdlus ei ole Aaviku kasuks: Saareste kirjutas Aaviku 70. sünnipäevaks tasakaaluka artikli „Üksiku ja üldsuse osast keeleelus. Johannes Aaviku elutöö puhul” (Saareste 1951). Samal ajal kirjutas Aavik ümber oma sõjaaegset päevaraamatut, milles korduvad kallaletungid Saarestele. Suur plaan puudub ka Aaviku alatises virinas kõnekeelevigade pärast. Aina ja aina leiavad taunimist ühed ja samad näited eila, praegult, praegust, ylesse, kodu minema (12, 124, 167, 225-229, 498, 514-515, 520-521, 549).

\section{Aaviku võõrkeeled}

Ladina keel oli Aaviku eriline huvi juba varasest noorusest (206). Hiljem on ladina keele grammatiliste vormide rohkus ning grammatikareeglite keerukus nähtavasti inspireerinud Aavikut leiutama sama keerulisi reegleid eesti keelde (146-148, 188). Ka klassikalise kreeka keele vastu tundis ta huvi ja lugupidamist samadel põhjustel.

Sõja-aastatel on Aavik tegelnud Johannese Ilmutuse raamatu uustõlkimisega kreeka keelest uuenduslikku eesti keelde (446-448). Aaviku unistuseks oli kogu Piibel uuenduslikus keeles välja anda (449-450). Aavik pidas ennast heaks ja peene stiilitajuga tõlkijaks ning oma päevaraamatus pühendab ta tõlkimiskunstile mitugi lehekülge (184-186).

Prantsuse keelele, mida Aavik väga hästi oskas, andis ta kõrge hinnangu ka selle tõttu, et prantsuse keel on ladina keele tütarkeel (43-44, 207). Mõne oma varasema keelealase töö ja ka osalt „Ruthi” on ta algselt kirjutanud prantsuse keeles $(44,215)$. Hoolimata oma russofoobiast hindas ta vene keelt väga kõrgelt (686) ja muidugi oskas seda keelt hästi.

Kõige tähtsamaks võõrkeeleks eesti koolis pidas Aavik saksa keelt (157), aga kõige põhjalikumalt kirjutab ta ladina keele õpetamisest (157-166). Aaviku näpunäited ladina keele hääldamise kohta oleksid väga vajalikud ka tänapäeva interpreetidele, Klassikaraadio diktoritele, koorijuhtidele ja repetiitoritele. Eesti keeles hääldati ladina keelt 1990-ndate aastateni traditsiooniliselt saksa häälduse järgi (väheste erinevustega diftongide hääldamises) koos juba saksa häälduses traditsiooniks saanud vokaalipikkuste vigadega. Valed vokaalipikkused on küllap üllatuseks paljudele, nii harjunud ollakse sellega. Lühikese esisilbivokaaliga peaksid olema näiteks amor, bonus (hea), genus, lupus, mare (meri), modus, novus (uus), pater, senior, status (quo), studium, sumus (oleme), tabula jpt üldiselt tuntud ladina keele sõnad. Pika esisilbivokaaliga peaksid olema insula (saar), jus (õigus), justus (õiglane), lex (seadus), lux (valgus), mater, rex ja regina, nos ja vos (meie, teie) jpt. Osa nendest näitesõnadest on õigekeelsusnormidega kinnistatud eesti kirjakeelde algkeelest erineva vokaalipikkusega (boonus, geenus, moodus, seenior, staatus, stuudium), seda pole tõesti mõtet üritada tagasi pöörata.

Kuid valed vokaalipikkused pole tänapäeval isegi mitte pool häda. Aavik ei võinud aimata, et kui Eesti jälle riigiks saab, siis hakatakse unustama ladina keele hääldamise saksa traditsiooni (mis on kõige lähemal ladina keele omaaegsele hääldamisele) ja maad võtab ladina keele hääldamine inglise kee- 
le hääldusreeglite järgi (mis on kõige enam kaugenenud elava ladina keele tegelikust hääldamisest).

Aavik toob „Ideepes” ja ka raamatus „20 Euroopa keelt” näiteid ingliskeelsetest hääldustest: agere hääldatakse eidzere (165; vist trükiviga, peaks olema eidžere), Numantia - njumänšja (Aavik 1933: 17). Ta esitab näiteid ka ladina keele romaani tütarkeeltest (itaalia, prantsuse, hispaania), kus ladina $g$ on eesvokaalide ees palataliseerunud. See $\mathrm{k} / \mathrm{g}$ palataliseerumine on üldtuntud foneetiline protsess, silmatorkavalt esindatud ka meie lähedastes sugulaskeeltes, vadja ja salatsiliivi keeles: küla on vadja keeles tš̈̈lä ja salatsiliivi keeles t'ula (palataliseeritud $t$ ), küsib on vadja keeles tšüzüb ja salatsiliivi keeles t'uzub (vrd ka vene keele рука - ручка, око - очи).

Ladina keeles sellist muutust polnud ja pole ka meil siin ladina kultuurist kaugele jäävas provintsis vaja seda ladina keelde tagantjärele istutada, lauldes Salve, Redžiina ja paanis anžeelikus.

\section{Foneetika}

\section{$\ddot{\boldsymbol{u}}$ ja $\boldsymbol{y}$}

Aavik liigitab $y$ (pro $\ddot{u}$ ) suurimate keeleuuenduste hulka (6). Aavikul puudus arusaamine tähemärgi konventsionaalsusest. Ühe kirjatähe kuju muutus ei muuda keeles mitte midagi. Hääliku $\ddot{u}$ väärtus (valeur Saussure’i mõttes) ei sõltu sellest, kuidas seda kirjutada. Alles siis, kui $\ddot{u}$ esinemus eesti keele häälikusüsteemis muutuks, saaks rääkida keele muutumisest.

Ja kuidas jääb pärisnimedega? Kas Aavik tohtis kirjutada Sytiste, nagu ta tegi? Aga $\ddot{u}$ Eesti ala saksa päritolu nimedes? Aga Saksa nimedes?

\section{$\boldsymbol{e} \boldsymbol{a}-\ddot{a} \ddot{\boldsymbol{a}}$}

Mõnes keeleuuenduse ettepanekus puudub isegi teoreetilise mõtlemise simuleerimine. Selged näited on ea-ää küsimus ja järgsilbi $o$. Aavik lahendas $e a-$ $\ddot{a} \ddot{a}$-vaidluse nii: „ea-ää - kysimus on lahendet kompromissi teel: yhelt poolt hea, teiselt poolt aga pä̈̈, pääl, sääl, tääl, säädma, aga seadus" (7).

\section{Järgsilbi o elustamine}

Järgsilbi $o$ elustamine on Aaviku enda hinnangul kõige suurem ja kõige raskem uuend (7). Raskuse osas on see tõsi, sest $o$ elustamine on häälikumuutuse tagasipööramine, mis on võrdlev-ajaloolise keeleteaduse järgi sama võimatu kui aja tagurpidi käimapanek.

Järgsilbi $o$ kokkusulamine $u$-ga oli keeleajaloos võimalik seetõttu, et tähenduste eristamisel oli $o-u$ vastanduse funktsionaalne koormus järgsilpides väga väike, erinevalt soome keelest, kus tähendust eristav $o-u$ vastandus järgsilpides on süstemaatiline: olot 'olud, olukorrad' - olut 'õlu', lato 'küün' latu 'suusarada', korot 'intressid' - korut 'ehted', hajota 'hajuda' - hajuta 'haiseda, lõhnata' jt. Eesti kirjakeeles saaks selliseid sõnapaare konstrueerida ainult siis, kui Aaviku ettepanekute järgi osa järgsilpide $u$-dest asendada o-ga: kulo 'kuluhein, rohi' - kulu 'väljaminek, kulutus'; magu 'maik' - mago 'seedimis-orgaan' $(7,363)$. Isegi kui eeldada, et ühe hääliku asendamine teatud positsioonis oleks äraõpitav, siis vajataks selleks ikkagi mingit reeglipära või süsteemi. 
Aavik viitab järgsilbi $o$ sisseviimisel pretsedendile soome kirjakeeles, kus $s$-i ja $t$ nõrga astme murdeti varieeruv hääldus otsustati ühtlustada osalt kunstlikult häälikusüsteemi poogitud $d$ abil (vesi : veden, lato : ladon 'küün : küüni' jpt). Siin piiritleb $d$ kasutamise astmevaheldus: nõrgas astmes on kindla foneetilise struktuuriga sõnades vaheldused $s: d$ ja $t: d$. Selline selgus Aavikul puudub. Tema otsustab ainuisikuliselt ja meelevaldselt, missugustes sõnades keeleuuendus asendab $u$ järgsilbis $o$-ga ja missugustes mitte: „Mitte iga järgsilbilise $u$ asemel ei ole $o$, vaid ainolt teatavate asemel” (700).

Tõsi, Aavik viib järgsilpi $o$ või säilitab seal $u$ mõningal määral sõna sisestruktuuri arvesse võttes: $m i k$-, stik-, lik-tuletusliidete puhul on tal $o$, samuti $n g$-, $k$-liidete puhul ja lühikeses mitmuse osastavas (võgrad : võkro 'ümberkirjutamisvead'), aga näiteks uma-refleksiivid ja $u s$-liide jäävad $u$-liseks, mistõttu tekivad vokaalivastandused, nagu harjuma - harjotama, haudoma (transitiivne: kanad munade peal) - hauduma (intransitiivne: puder pliidi peal).

Ikka jääb veel 400-600 sõna (neist 70 suure sagedusega), mis tuleb lihtsalt uuesti omandada. Ja mispärast? Sest Aavik soovib nii. Ka Aavik ise eksib nii ebamääraste orientiiridega liigituse vastu (ebajärjekindlused võivad olla ka ümberkirjutamisvead, võgrad).

Aaviku $o$-sõnade loendis kumab läbi soome keel. Kas siis uuendusliku eesti keele äraõppimiseks peab enne ära õppima soome keele? Eesti ning soome keele mitteühise sõnavara puhul ei aitaks ka soome keele oskus. Ja siingi pole järjekindlust: „Soomekeelest erinevalt u-ga on elu, kogu, olu, ilu, ilus” (7, ka 363). Vastupidiseks näiteks on Aaviku pauko (sm paukku). Võrumaa ja Setu ala keel oleks järgsilbi $o$ põhjendamiseks sobinud paremini, aga lõunaeesti keelega Aavik ei arvestanud. Tema üleskutsed uurida rahvakeelt ja murdeid kõlavad „Ideepe” taustal õõnsalt. Kui Aavik oleks oma tahteavaldustele vajanud mingisuguseidki põhjendusi, siis oleks ta võinud toetuda ka rahvalauludele, mida ta hästi tundis ja kõrgelt hindas.

Aga Aavik ei hoolinud isegi rahvalaulude järgsilbi-o-st. Näiteks jäävad Aavikul $u$-listeks neiu ja peiu, ka minu ja $m u$, mis rahvalauludes üle Eesti on sageli o-lised (neiokene jne; seda ka tema enda koostatud kogulmas „Valik rahvalaule” (Aavik 1919, vt nt „Salme laul”, lk 86-92).

Elustet järgsilbi-o puhul oleks arvesse saanud tulla ainult üks võimalus: anda selle kasutamine täiesti vabaks, vaba variatsiooni valdkonda, nii et $u$ ja $o$ oleksid järgsilbis ühe foneemi vabalt vahelduvad variandid, mille erinevus ei muuda tähendust, sest $u>o$ asenduseks puudub funktsionaalse argument. Kes suudaks meeles pidada, kas peab olema lõbojano, lõbujano, lõbojanu või lõbujanu, kas tantsopido, tantsupido, tantsopidu või tantsupidu, kas vastopano, vastupano, vastopanu või vastupanu, kas eeskujo mõju või eeskuju mõjo?

\section{$\check{\boldsymbol{z}}$}

Mõned Aaviku õigekeelsuslikud vaated olid üsna traditsiooniliselt vigased: näiteks, et koolis on vaja õpetada $\check{z}$ helilist hääldamist (16), mis on eesti hääldussüsteemi vastane ja foneetiliseltki võimatu näiteks ühendites nagu prestiižse, samuti ž-le järgneva ki-liite korral (loožki, beežki).

Aaviku foneetikas - ei keeleuuenduslikus ega traditsioonilises - pole parimagi tahtmise juures võimalik näha keeleteadust. 


\section{Fonotaktika}

Fonotaktika määrab ära sõnavormide võimalikud foneetilised kujud: missugused häälikujärjendid on võimalikud ja missugused mitte, kus kohas (silbi algusena, tuumana, lõpuna, rõhulises või rõhuta silbis, järgsilpides) ühed või teised häälikud ja häälikujärjendid saavad esineda.

Fonotaktika annab keele häälikusüsteemile kindla vormi, mis igas keeles ja keelemurdes on erinev. Keele fonotaktika muutub ajas - enamik häälikumuutusi on fonotaktika muutused: üks või teine häälik või häälikujärjend muutub teatud positsioonis. Näiteks kadus eesti keeleala valdavas osas suhteliselt hiljuti järgsilpides $o$ (enamasti $o>u$ ).

Aavik tunnustas keele foneetilise homogeensuse silmaspidamise vajadust ka keeleuuenduses (1924: 22-31), aga oma uuendusettepanekutes ignoreeris ta seda põhimõtet sageli.

Iga kord kui fonotaktika reegleid eiratakse, on võimalik arutleda, kas eksiti süsteemi reeglite vastu või laiendati süsteemi võimalusi. Esimesega on tegemist näiteks uudissõnavõistluse nimetuses sõna-us (silbipiir vokaalijärjendis); süsteemi laienemiseks võib pidada eesti keelele mitteomase diftongi $e u$ kinnistumist seoses eurorahaga (ka Aavikul on leuded ilmad 'pehmed ilmad'; 692).

Aaviku uus käändevorm g-relatiiv on fonotaktiliselt küsitav, sest eesti omasõnades ei esine $g$ esisilbist kaugemal sõna lõpus silbilõpuna [Aavikul „... see ei sobi teoseile määratug noorsoole"; (362) = '... mis on määratud ...']. Kas see on sulghäälikute esinemissüsteemi täiendamine ( $b$ ja $d$ esinevad sellises asendis: vä̈̈ratab, mä̈̈ratud) või fonotaktika vastu eksimine? Pigem viimane.

Aaviku soovitatud keelendid eksivad eesti keele põhiliste murrete ja ka kirjakeele fonotaktika vastu päris sageli.

Eesti kirjakeeles ei lõpe omasõna järgsilp diftongiga. Aavikul esineb järgsilbilõpuline diftong mitmuse omastava tüve lõpus: „... suur huvitavi raamatui hulk ees...." (501). Järgsilbilõpulist diftongi on ju kasutatud ka Aavikust sõltumatult („Su ümber on sõprade leinai koor” - Henrik Visnapuu), aga kirjakeeles pole see püsima jäänud.

Teiseks kasutas Aavik sõnalõpulist diftongi lihtmineviku tema-isikus: osutui (69), nakatui (317), alistui (327, 477), opteerui (415), peegeldui (445), sisaldui (451), võimaldui (592), haigestui (648) jpt näiteid - see on otseülevõtt soome keelest.

Eesti kirjakeeles ei esine diftong esma- ja teisevälteliste sõnade teises silbis, soome keeles saab lühisilbi järel teises silbis diftong esineda. Aavik võttis soome keelest üle tegusõna ihailema (nt 188).

Eesti kirjakeeles ei ole lubatud ji-järjend. Aavik soovitas järjekindlalt ülivõrde vorme märjim, kurjim, lai’im $(6,108)$, soojim (342), samuti lühikesi mitmuse vorme nagu kõigist kyljist (590).

Eesti kirjakeeles ei kuulu uuv-järjend tavaliste häälikujärjendite hulka. Aavik soovitas kunstsõnu nagu juuvima 'heaks kiitma' (34, 133, 284), luuvik : luuviko 'lagendik' (106, 511, 692).

Eesti keeles kehtib järgsilpide puhul reegel: sõnasisene silp algab konsonandiga. Vähesed erandid on avaus, ärkamisaegne paleus ja Marie Underil esinev hõllaus, kus sõnasisest vokaalijärjendit poolitab silbipiir. 2010.2011. aastal toodi president T. H. Ilvese väljakuulutatud uudissõnavõistluse 
nimetusena korraks uuesti käibesse sõnaus ning pole ime, et seda ei osanud esialgu hääldada isegi raadiodiktorid. Tänapäevases keeles liitub -us konsonandile (vabadus, pimedus, ka kurbus, ahnus jne; teisiti on soome keeles: vapa-us, pime-ys, ahne-us).

Aaviku soovitatud uuenduslikest verbi grammatilistest vormidest peetaes, käinue, möödutue (nendest lähemalt tagapool) esimeses tuleb vokaaljärjendit a-e hääldada kahes silbis: peeta-es (Aavik joonealuses märkuses lk 8). Kas käinue tuleb hääldada käi-nue (kaks silpi, eesti keeles puuduva diftongiga ue) või käi-nuu-(w)e (nagu käin + uue), selle kohta Aavik juhtnööre ei anna; sama küsimus on tue-ga; ning nne-gerundiivilgi on järgsilbi $n n$-geminaadi näol fonotaktiline probleem (selle saavutanne; 71).

Fonotaktiline eksimus on Aaviku konjugeerimisviis säädma : säan, kus nõrga astme tüvevariant on pigem kahesilbiline $s \ddot{a}-a n$, sä-aksin, sä-ab jne (256, 535, 561, 654).

Aaviku „Valik rahvalaule” (1919) esitas vokaalijärjendiga laadivahelduslikud nõrga astme vormid tihti silbipiirimärgiga, näiteks laulus „Abikaasa tapja Mai” tantsis Tarretu mä’ella, teravil no’aterilla. Refräänina korduvas „Säa sääred Maiekene, säa sääred katsu kannad!" (Aavik 1919: 98-102) on küll silbipiir märkimata, aga rahvalaulu värsimõõt ja foneetiline paratamatus määravad $\ddot{a}$ - $a$ kahe silbi järjendiks.

„Valik rahvalaule” ilmus ajal, mil laadivahelduslike sõnade nõrga astme vormide vokaalijärjendite kokkutõmbumine ühte silpi kuuluvateks hilisdiftongideks polnud veel lõppenud. Tolle aja grammatikad tõlgendavad selliseid vokaalijärjendeid kahe silbina ning ka „Keeleuuenduse äärmised võimalused” ütleb, et lo-en on kahesilbiline (Aavik 1924: 50). Sõnasisese silbi konsonandiga algamise reegli üldistumine kiirendas selliste vokaalijärjendite kokkutõmbumist ühte silpi kuuluvateks hilisdiftongideks - seal, kus see on foneetiliselt võimalik; $\ddot{a}-a$ pole diftongi andnud.

Üldiselt esineb kõnealune refrään laulu põhjaeesti variantides kujul „Sea sääred...” (Laugaste 1948: 334-337). Se-a käib rahvalaulus kahe silbi ette, lõunaeesti säe oleks rahvalaulus hääldatav nii ühes kui ka kahes silbis. Aavik eelistab „Ideepes” kõige erandlikumat kahesilbilist $a$-tüvelist konjugeerimist: säädma : sääda : sä-an. Siiski tunneb ta ka teisi võimalusi: „Berójeva läheb sinna säetud tunnil" (634).

„Keeleuuenduse äärmistes võimalustes” (kirjutatud 1918, ilmunud 1924) oli Aaviku seisukoht, et hilisdiftongid (mille hulgas ta lk 53 loetleb ka äa ja Ain Kaalepi sõna teavitamine ea) pole kunsttüvedes nii kõlblikud kui pärisdiftongid. Hilisdiftonge vältis Aavik kunsttüvede esisilpides ka hiljem. Seda järjekindlusetum, et grammatilistes vormides nagu säädma : säan, peetaes, näinue, möödutue kasutab ta problemaatilisi vokaalijärjendeid. Eesti omasõnade järgsilpides on ülepea võimalikud üksnes $i$-lõpulised diftongid, mistõttu ka ae (peetaes jts) ei saagi häälduda diftongina, vaid üksnes reeglivastase vokaalijärjendina peeta-es.

Aavik ignoreerib $\boldsymbol{h}$-hääliku esinemispiiranguid eesti kirjakeeles: need piirangud ei luba konsonantühendeid, mille teiseks liikmeks oleks $h$; üldisemalt üteldes ei esine $h$ eesti kirjakeeles pika silbi järel ega järgsilpides. Aavik soovitab „Ideepes” uuenduslikku keelde hulga soome sõnu, mis rikuvad seda reeglit: jylhesti (73) ja jylhe (107), tuuhe (102, 107), vaihe (114), aihe (273), kauhistus (267, 509, 682), laihtuma (653, 714), lauhke (714), tuulahtama 
(420, 719). Aavik teadis, et jylhe eksib eesti foneetika vastu (Aavik 1924: 65), aga „Ideepes” hoolib ta sellest veel vähem kui paarkümmend aastat varem.

Ka reeglivastaste $h$-sõnade ning sõnalõpulise diftongi puhul oleks Aavik võinud tuge otsida Võru murdest, aga tema põlastus lõunaeesti keele vastu välistas selle vähegi mõistliku argumendi.

Mõnda Aaviku kunstsõna on raske hääldada: $r$-r-ga rort : rorda 'ropp elu' ja rordatsema 'roppu elu elama' (655-657), ka rääderdama 'halvasti kohtlema, kiusama' (206).

\section{Aaviku kunstsõnade loomise ja sõnade laenamise põhimõtted}

Aaviku kunstsõnade loomist innustas teooriat asendanud kinnisidee, et tähtsamate võõrkeelte sõnade iga tähendusvarjundi vasteks tuleb eesti keeles leiutada omaette tüvisõna. Selline seisukoht ignoreerib keele olemust. Kõigis keeltes on suur osa üldsõnavarast keeleomaste tähendusnüanssidega ja teisiti see ei saagi olla, sest keeled on läbi teinud erineva ajaloo ja elavad erinevates tingimustes. Selle vastu sõdida on mõttetu. Aga Aavik arvab, et vene восторг ei ole täpselt vaimustus, et veskilik jälitama ei ole hea vaste vene verbile преследовать, jne.

Sõnavararikas eesti keel on motiveeriv eesmärk, kuid Aaviku mõtte järgimine sõnavara täiendamisel viiks - kui seda lõpmatuseni teha - selleni, et eesti keele sõnadesse istutatakse võõrkeelte sõnade tähendusstruktuur (selline taotlus kumas läbi ka president T. H. Ilvese saatemuusikast 2010.-2011. aasta „Sõnausele”). Keeltevaheline tähenduste täpne vastavus on vajalik teaduslikus ja tehnilises terminoloogias, mitte üldkeeles.

Uutele sõnadele kuju andmisel eelistas Aavik keeleminevikku, tema uustüvedel on ikka ja jälle keeleajaloo tunnused. Ta leidis, et ebaproduktiivseks muutunud tüvevokaalid $-a$ ja $-u$ on suursugusemad kui produktiivne $-i$, et tüvevaheldused, eriti laadivaheldus ja tegusõnade konsonanttüvi (sembama: semmata 'külge tõmbama', numelema : numelda 'kahe vahel olema') ning üleüldse kõik arhailine on vähem banaalne kui reeglipärasus.

Kirjeldades Turgenevi novellide tõlke sünnitusvalusid (307-309) ja Kreutzwaldi „Eesti rahva ennemuistsete juttude” redigeerimist uuenduslikku keelde (323-326 jm), loetleb ta kümneid uusi tüvisõnu, millest suur osa on ju õnnestunud. Eriti sobivad oleksid need sõnad siis, kui nad oleksid keeles olemas olnud esivanemate pärandina. See märkus ei ole mõeldud Aaviku leidlikkuse halvustamiseks. Aaviku taotluseks oli võimalikult mitmekesine keelevahendite repertuaar. Selleks pani ta kokku keeleajaloo erinevad ajastud, tänapäevased ja arhailised muutmistüübid. Aavik eelistas keeruliste reeglitega morfoloogilisi tüüpe ning selles põhimõttes ta järeleandmisi ei teinud, kuigi praktiseeriva õpetajana pidi ta teadma, missugused morfoloogilised tüübid on õppijatele kerged ja missugused rasked.

$a$ - ja $u$-tüveliste nimisõnade hulgast võib leida nii täiesti kunstlikke (nisv : nisva 'pahe, patt', naum : nauma 'puuvili', sõun : sõunu 'hääl, kõla') kui ka teiste keelte assotsiatsioonidel põhinevaid (mork : morga 'pimedus, vn мрак', loir : loiru 'auhiilgus, pr gloire'). Konsonanttüveliste tegusõnade hulgast leiab nii kunstlikke (numelema : numelda) kui ka selliseid, mis on kombineeritud määrsõna ja tegusõna ühendist (kaatma : kaadan 'korda saatma', võstma : 
võstan 'vastu võtma', vyltma : vyldan 'üle võtma'). Kuigi Aavik seda ei märgi, on saksa keele Hof machen 'kurameerima' läbinähtav tegusõnas hoovistelema : hoovistella : hoovistelen 'kellelegi (naisele) hoovi tegema' (543, 633, 712; kuid on küsitav, kas sõnaseletus 'hoovi tegema' ütleb midagi saksa keelt mitteoskavale eestlasele).

Mõned Aaviku uuendused on olemasolevate sõnade häälikulised teisendid: ketkestama $(713)<$ katkestama; põgu : põo : põkko minema $(658)<$ pagemine, põgenemine; siham-suham $(667)<$ sihin-sahin.

Soome keelest võttis Aavik sõnu üle nii muutmata kujul kui ka neid mingil määral eestistades. Soome sõnade ülevõtmisega kaasnes nende tihti eesti keelele sobimatu fonotaktika. Järgnev on ainult lühiloend Aaviku „Ideepe” soome sõnadest, mille hädavajalikkuses võib kahelda: aego saama (173), paljo aegosaav riigimees (284), alue (348, 540), asu 'kuju, vorm' (392), hööduma 'sm hyötyä' (690), kerdoma (713), kygenema, laihtuma (653), melgone (714), muga (641), mutkikas, paitsi (Aaviku soovitatud II välde on küsitav), pohtima : pohin (313), rappeutuma (680), savutama (509), vaeldamine (719), vail (58).

Fennismid esinevad Aavikul sõnakolooniatena: võib mööduda lehekülgi ilma fennismideta, ja siis on äkki teksti tipitud mitte just kõige vajalikumaid soome sõnu: kerdoda, yhä tugalamaks, rymu (175-176; viimane on „Ideepe” esimese osa sõnastikus märgitud kunstsõnana, teise osa sõnastikus prantsuse mõjuga kunstsõnana, seega arvatavasti < rumeur; rymy on ka soome keeles olemas tähenduses 'kära, lärm'; see ei saanud Aavikule teadmata olla).

Elades oma keeleuuenduslikus ja võõrkeeltest tõlkimise maailmas, võis Aavik hakata loomulikust eesti keelest võõrduma, talle võis hakata paistma, et eesti keel vajab otse igas kohas ümbertegemist.

Selle poolt räägivad juhuslikud sõnad ja grammatilised vormid, mis 700 tihedal leheküljel tulevad ette ainult korra või paar: see : sehe (592) nagu maa : maha, saksa keele eessõnaga seit paar aastat (616), ... vyrst pojandab lapse.... (667). Kindlasti on pojandab lapse leidlikult tuletatud, värske ja huvitav, aga tütre puhul ei tuleks see välja, siis tuleks ikkagi ütelda lapsendas tüdruku (tütardas oleks jabur ja reeglikohane tütrendas pole pooltki nii elegantne kui pojandas); ka lapsendas poisi tuleks toime ilma pojandamiseta. Hetkepähepist näib olevat tollal veel eesti keeles kodunematu eu-diftongiga leuded 'pehmed' ilmad (692; otseülevõtt soome keelest < leuto); või kas on vaja omaette sõna rell : rella tunnikella jaoks (717; ja siis veel seinrell; 718)?

Aaviku meelepaha kutsuvad esile mõningad omapärased eesti liitsõnad, mille tähendus ei sõltu osiste järjekorrast: tasapisi $=$ pisitasa, segiläbi $=l \ddot{a} b i$ segi. Aavik keelaks esimesed variandid $(170,519)$. Nendele saab lisada veel meelepaha = pahameel (vrd: meelehea ja heameel pole sugugi sama tähendusega).

Satub ka, et Aavikul endalgi läheb oma kunstsõna meelest: üldiselt on tal majad yhe-, kahe-, kolmevooksed, aga üks puumaja on ühekordne (103).

Uute eesti tüvisõnade leiutamise palaviku kõrval näib Aaviku võõrsõnatarvitus paradoksaalne. Aaviku võõrsõnad on mõnikord vanamoodsad (materjaal, restoraan, kartotekiseerima), vene või saksa keele pärased (apsats, front, heft, kolleega, korridor, list, liiferdama (629: „Ka liiferdas ta rikkaile härradelle noori tydrukoid armokesteks ....”) või väga erudeeritud (anodiinne, afrontima $<$ ? pr affronter, lastsiivne tants 'häbitu kiimaline tants' < lad, ogiivvõlv 'gooti teravkaarvõlv' < pr, pandaanid, ruiin 'ruineerimine' jpt). 
Kunsttüvede väljamõtlemine oli Aaviku hinnangul raske töö, mis tal enda arvates enamasti õnnestus. Aaviku kriteeriumide järgi see nii ongi, aga need kriteeriumid on ad hoc, vastavalt hetketundele.

Mõnd foneetiliselt homogeensetki kunstsõna ei saa õnnestunuks pidada: malnis 'juuresolev' (ka verbina malnitsema; 465) ja älnis 'äraolev' liituvad foneetilise ja morfoloogilise tüübi poolest omadusi väljendavate sõnadega nagu sulnis 'meeldiv-magus (sulnid mõtted)' ja miivis 'naiivne'. Seetõttu tendeerib assotsiatsioon paigutama kõik nad kokku ühe tähendusvälja sõnadeks (vrd ka jaunis, jallis, kallis). Ent Aaviku tahe on malni ja älni pannud tähendama ruumilisi suhteid: malnid 'juuresviibivad' ja älnid 'äraolevad' sõbrad.

Mõni Aaviku kunstsõna on Aaviku antud tähenduse kaotanud ning meie ajal hakanud tähendama hoopis midagi muud: üllitama 'ässitama' > 'trükis avaldama', heroiin on Aavikul mõistetavalt 'kangelanna' (589), tiivik : tiiviko 'majatiib' (655) on muutunud pigem tehniliseks terminiks.

\section{Aaviku keeleuuendustaotlused grammatikas}

Et ühel grammatilisel vormil on erinevaid funktsioone või et sama funktsiooni väljendatakse erinevate vormidega (eesti keeles näiteks sihitise käänded), selline olukord kujuneb kõigis loomulikes keeltes keele muutumise tõttu täiesti paratamatult. Keelekorraldus - ja keeleuuendus on keelekorralduse üks meetodeid - saab seda olukorda ainult väga vähe muuta. Üheski keeles ei ole nii, et käänetel, ees- ja tagasõnadel ning infiniitsetel verbivormidel oleks ainult üks funktsioon.

Kui püüda mitme funktsiooniga grammatilise vormi igale funktsioonile leiutada uus omaette grammatiline vorm, siis on tulemuseks suur grammatiliste vormide hulk, millest igaühe kasutamissagedus langeb, nii et vormistiku kinnistumine muutub raskemaks. Aavik aga töötas just põhimõttel i g a le funktsioonile omaette vorm. Kuid tema endagi tekst tõendab, et mõnda uuendust ei kasuta ta kümnete lehekülgede ulatuses ühtki korda.

Uute grammatiliste vormide leiutamisel tuleks arvestada nende hääldatavust (fonotaktilist sobivust) ja seda, et nad ei oleks vastuolus keele tüpoloogiaga. Aavik ei hoolinud kummastki nõudest: tema leiutatud gerundiivid on hääldamise seisukohalt problemaatilised ning no-genitiiv ja artikkel pole eesti keele tüpoloogiaga sobitatavad. Aaviku uuendusettepanekud sõltusid tema võõrkeelteoskusest ja tõlkimistegevusest. Araabia muinasjutte lugedes leidis ta, et eesti keeles oleks vaja artiklit ning selleks sobiks araabia keele silp el: „sambarikas; vrd.: el sambarikas” (66).

Grammatika radikaalsed uuendused on Aavikul mõttes olnud aastakümneid. Enamus järgneva loendi ettepanekutest on esindatud juba „Keeleuuenduse äärmistes võimalustes” (1924), kuid alles „Ideepes” sai ta neid piiranguteta kasutada. Järgnevas analüüsitakse üksnes Aaviku kõige suurejoonelisemaid eeteid, mis heidavad valgust tema mõtteviisile ja keeleuuenduse ideoloogiale.

Suurimate ja tähtsaimate keeleuuenduste hulka arvab Aavik (6-8):

- ma-infinitiivi käänded -maks, -maga, -mani, -malt, -mast;

- n-agentaali;

- umbisikulise es-gerundiivi (kõnet peetaes = 'kõnepidamise ajal kellengi teisen'; 8); 
- nue- ja tue-gerundiivid (teinue = olles teinud; möödutue = kui ollakse möödutud);

- -tulg : -tulje (-tud olek, -tus; tapetulg = 'tapet olek');

- -neip : -neiba (nt märterneip = 'märter olemine')

- -lisv : -lisve (-lisus);

- no-genitiivi;

- kelled-milled, kende-minde, kendel-mindel jne;

- käänamise õnneto : õnnetoma : õnnetond;

- pärisnimekujulise omadussõna eestineen : eestineena või eestinesk : eestinesa (nt eestinesk rahvaluule).

\section{ma-infinitiivi käändevormid}

$m a$-infinitiivi käändevormide väljaarendamise arvas Aavik kõige tähtsamate keeleuuenduste hulka. Osa ma-infinitiivi käändevorme on ammu nn ametlikku grammatikasse inkorporeeritud, osa on uuenduslikud, aga ka esimestele leidis Aavik uusi funktsioone. Kui vajalikud-otstarbekad need uuendused on?

\section{Seesütlev (inessiiv): -mas}

$m a$-tegevusnime seesütlevale on Aavik leidnud uudse funktsiooni, mis ühes näitelauses väljendab kolm korda tähendust (seisneb) selles, et $+d a$-infinitiiv: „Kogu töö seisneb koostamas sobiv vigade nomenklatuur ja jaotamas need eri vihikoisse ning siis moodostamas neile harjotuslaused" (431). See on hoiatav näide Aaviku kergekäelisusest: tuli pähepist proovida mas-vormi uudses funktsioonis ja läks lahti! Kuigi tulemuseks on ainult ühe sidesõna selles et kokkuhoid: Kogu töö seisneb selles, et koostada ...

\section{Seestütlev (elatiiv): -mast}

-mast on eesti keeles $m a$-infinitiivi käändevormina eitava sisuga konstruktsioonides olemas ka ilma keeleuuenduseta: keeldus tegemast, hoidus embamast jne. Aavik kasutab seda vormi ka teistsuguses seoses: „... Maaša oli õnneto pidamast lahkuma armsate kasuvanemate juurest...." (637). See on väga harjumatu mast-vormi kasutamine ega ole parem kui „...Maaša oli õnneto, et pidi lahkuma....” Sama käib järgmise näite kohta: „... kahetsesin mitte näinumast kogu filmi" (676). Kui 700 leheküljel on seda vormi uudses seoses kasutatud ainult paar korda, siis võib kahelda, kas uuendus on elujõuline. Lisaks on nende konstruktsioonide tähenduse analüüs üsna raske (pidamast on määratlemata ajaga, näinumast on minevikuline).

\section{Alaltütlev (ablatiiv): -malt}

-malt on hetkeuiu moodi vorm, mille grammatilise tähenduse analüüs on problemaatiline: „See karjamaa on mulle väga tuttav mu olemalt sääl ....poisina rohkesti viibind...." (583). Aavik ise on seda kasutanud võib-olla ainult üks kord 700 leheküljel.

\section{Rajav (terminatiiv): -mani}

Sellegi vormi kasutamine on Aavikul väga harv, aga siis talle järsku justkui meenub see -mani ja kahel järjestikusel päeval kirjutab ta: „Läksin koguni soovimani....”, „Läksin koguni kavatsemani....” (220). Need näited on selle vormi soovitamiseks üsna ebasoodsad: luua uus grammatiline vorm väheste konstruktsioonide jaoks on keele jaoks ebaefektiivne investeering. Üpris kohmakas on „... sellal ei jõutud välja andmani.... valikkogulmat...” (272). 


\section{Saav (translatiiv): -maks}

„Ta läheb ... kalmistolle otsimaks sääl yles oma naise haua...” (674). See vorm on ka nn ametlikus grammatikas harva kasutatavana olemas ja Aavikulgi on ta ülimalt harv.

\section{Kaasaütlev (komitatiiv): -maga}

Uuendusliku maga-vormi asendajateks tavalises kirjakeeles on des-vorm, harvem -misega või $d a$-infinitiiv: „... see mul yndis esmakordselt toetamaga viiuli kaela otsa vasto seina" $(69)=\ldots$ toetades ...; ,... talle andmaga suuremad karistamise võimalused...." (138) = ... talle andes ...; „Ma teen ôpilase intelligentsi astme kindlaks pelga laskmaga teda sõnade välteid määrata" (286) = ...pelgalt lastes ... (selline intelligentsiastme määramise viis ja sellest järelduste tegemine on kindlasti ebaobjektiivne); „Ylalpidamist.... hankis ta alul andmaga klaveritunde” $(664)=\ldots$ andes...; „...tema oli vyrsti veel kymme korda rohkem solvand võrgotamaga vyrstinna abielu rikkoma temaga...." (679) = ...võrgotades...

Mingit selget paremust maga-konstruktsiooni kasutamine ei anna.

\section{Gerundiivid: isikuline -nue, umbisikulised -ta-es, -tue}

Gerundiiv on tegusõna mittepöördeline (infiniitne) ehk sekundaarvorm, mis väljendab lause põhiverbiga samaaegset tegevust, seda määrsõnaliselt iseloomustades (saab küsida mil viisil? kuidas? mida tehes? mis olukorras? jt). Eesti normgrammatikas on ainult üks gerundiiv - des-vorm -, nt Maal puhates ta närvid rahunesid. Hüpates pääses tarast üle.

Teiste keelte eeskujul tahtis Aavik eesti keelde tuua täiendavate grammatiliste tähendustega gerundiivivorme. Tema uute gerundiividega seondub hääldamisprobleeme: umbisikulist es-gerundiivi tuleb hääldada kahes silbis (peeta-es), kuidas hääldada nue- ja tue-gerundiive, seda Aavik ei ütle (vt Fonotaktika).

-nue (= -nuna, -nud, olles -nud)

-nue asemel võiks enamasti seista nuna-vorm (või olles -nud): „Väljunue tookord ta juurest....” (210); „Koju naasnue anti talle äsja saabund kiri...” (672); „Seda hakkasin tegema näinue Pöide kirikut.” (kirikut u-ga; 99); „Lugenue läbi selle ligi 600-lehekyljelise raamatu...." (216).

Nagu mõne teisegi uuenduse, nii unustab Aavik ka -nue kasutamise pikaks ajaks, ja kui see meelde tärkab, siis tuleb uuenduslikku vormi robinal: „Kui ärkab, on vaenlaste salk juba ära läinud, röövinue paljaks ja põletanue talo ning tapnue ja vangi vedanue mitmed Kalevipoja mehed...." (270).

-nne on nue-gerundiivi variant pikema tüvega sõnades (362): Otsustanne (= olles otsustanud) seda.... (40); „Lõpetanne kooli....” (= lõpetanud; 460); „Siis tööst tydinenne (= tüdinuna) lamaksin kušetil....” (534); „... toon.... liigub selle saavutanne kohe keskjoone poole...." = (olles) selle saavutanud, liigub toon... (71; viiulimängust).

Umbisikulisele tue-gerundiivile sellelaadset varianti Aavik pole esitanud, kuigi on ilmselt taotlenud oma gerundiivide süsteemis sümmeetriat: oleviku ja mineviku gerundiivid nii isikuliselt kui ka umbisikuliselt. 


\section{Umbisikuline -ta-es}

„See muidogi muutvat Saksamaa seisukorra rahu tehtaes soodsamaks” (313). Aavik soovib grammatiliste vahenditega teha vahet, kas rahu teeb Saksamaa või Saksamaale tehakse rahu (nagu näitelauses). Niisuguseid erinevusi ei pea väljendatama grammatiliselt. Paarist selle gerundiivivormiga näitest „Ideepes” on üks selge tähenärimine: „...sulg,.... mis ei kratsi kirjotetaes.” (21) tähendab, et mitte sulg ise ei kirjuta, vaid sulg ei kratsi, kui temaga kirjutatakse! Tavalisest des-vormist aitaks küll: See sulg ei kratsi kirjutades. See vorm on üle võetud soome keele grammatikast (passiivi inessiiv).

Umbisikuline -tue (= kui ollakse -tud)

„Saueaugust möödutue tõuseb tee järsku kõrgemaks” (100). „Ideepes” esineb seda vormi üliharva.

Tuletusliited -tulg : -tulje, -neip : -neiba, -lisv : -lisve

-tulg : -tulje : -tulge (-tud olek, -tus) - sedagi ülitähtsate hulka arvatud uuendust ei esine „Ideepe” tekstis kümnete lehekülgede jooksul ja siis äkki on mitu sellist vormi: „Puudega kaetulje tõtto valitses selles uulitsa osas teatav niiskus....” (575); „...elada puhtas ja turvalisves eraldetuljes.” (579); „...õpetajad annaksid.... kirjaliko harjotusylesande, mille tehtulge nad järgmisel tunnil kontrollivad...." (321).

Normaalkeele tus-liide, mida Aavikul asendab -tulg, väljendab ka aspektilisust - näiteks harjutuse tehtust, sooritatust.

-neip : -neiba : -neipa - märterneip = märter olemine $(6) ;$ „... vist mõjus $m u$ inspektorneip eestikeele õpetajaisse...." (143). Siin on eos olemas koguni aega väljendav nimisõna tuletusliidete süsteem: märterneip olevikus, minevikus, tulevikus (nt märterneip, märternoip, märternuip). Aavik on jäänud poolele teele :-neiba lõpuni mõtlemine peaks sinna välja viima.

-lisv : -lisve (II välde) : -lisve (III välde) - ametlikus keeles -lisus: „... elada puhtas ja turvalisves eraldetuljes" (579).

Nõrgaastmelisi -tulje ja -lisve tuleks hääldada II vältes. Aga proovitagu eelnevaid näiteid häälega lugeda: kipub tulema III välde. Aaviku radikaalsed leiutused sobituvad halvasti isegi eesti keele lauserütmiga, mille asjatundja Aavik oli.

\section{k-relatiiv}

Radikaalne uuendus oli süntaktiliste funktsioonidega $k$-relatiiv. Sellega tahtis Aavik eesti keelde luua vene keele võimalustega võrdväärse, põhisõna suhtes järelasetusega täiendina funktsioneeriva käändelise verbivormi. Aavik väidab $k$-relatiivi leiutanuvat alles Rootsis 19 . juulil 1949 , seega on $k$-relatiivid „Ideepesse” lisatud päeviku ümberkirjutamisel 1950. aastal (8). Seegi näitab, et Aavik on „Ideepes” öeldavat hoolikalt viimistlenud.

Uus vorm võimaldab vältida täiendlauset alustavat siduvat asesõna, enamasti muud ei midagi (lauseanalüüs muutub natuke). Kui $k$-relatiivi aluseks olevad kesksõnalised täiendid tuua põhisõna ette, siis kaob ka see efekt. Koma ärajätmine $k$-relatiivse täiendi ees raskendab lausest arusaamist, Aavikul on nii komaga kui ka komata näiteid. 
„...gymnaasiumi, baseeruvak 4-klassilisel algkoolil." $(129)=\ldots$ mis basee$r u b \ldots=$...4-klassilisel algkoolil baseeruva gümnaasiumi; „... nagu inimene läbipõdenuk raske ja pikaldase haiguse.” (176) = ... kes on läbi põdenud ... ; „... piltidel määratuk fantastilistele jutustustele....” (273, joone all); „Ma ise loen meeleldi kommentaare lisatuk belletristilistele teostelle." (= belletristilistele teostelle lisatud kommentaare; de-mitmus Aaviku eelistatud $i$-mitmuse asemel; 307); „Ja mis saab siis maadest praego nandetuk sakslasin.... (561) = ... praegu sakslaste poolt okupeeritud maadest.

Viimases näitelauses võimaldab $k$-relatiiv + agentaal ehk tõepoolest ivake kompaktsemat väljendust. Aga küsimuseks jääb: kui kaugele saab kunstliku grammatikaga minna, et säiliks järjepidevus uuenduste-eelse grammatikaga?

„Ideepe” esimese osa keelelises kommentaaris esitab Aavik relatiivist uue, fonotaktiliselt küsitava g-lõpulise variandi ja näiteid selle kasutamisest: „... see ei sobi teoseile määratug noorsoole...." (362) = see ei sobi noorsoole määratud teostele. Mõni sellise vormi näide on tekstiski: „Ta eluloost paigotetug ta kogut teoste etteotsa ja kirjotetug ta austajan...." (681).

$k$-relatiiv sageneb „Ideepe” teises osas. Aavik on päeviku ümberkirjutamisel pidanud vajalikuks tuua sellest vormist rohkem näiteid. Oli ju Aaviku mõtteks permanentne keeleuuendus. Omaendagi varasemaid keeleuuenduslikke tekste oleks ta hiljem tahtnud töödelda veelgi uuenduslikumaks.

\section{n-agentaal}

Aavikule meeldis keeruline grammatika ning agentaal on selge sellekohane näide. Agentaal on tegijat väljendav kunstkääne, mida Aavik ise küllalt sageli kasutas. Mõni tekstilõik on tal läbinisti agentaalne (tihti ka umbisikuline). Näiteks „Ideepe” leheküljel 335 on kümnes reas viis agentaalivormi, aga siis võib minna palju lehekülgi ainsagi agentaalita. Mitu agentaali ühes lauses muudab lause raskesti analüüsitavaks: „... maja purusteti venelasin samal aastal Kuresaare vallotamises sakslasin" (579).

Tänapäevastes tegijafunktsiooni käsitlustes pole isegi viidet Aavikule, nii täielikult on agentaal keeleuurijate teadvusest kadunud (nt Sahkai 2011). Et agentaal on eraldi käändena tarbetu, seda on omal ajal nentinud ka Valter Tauli (1982b: 24).

Agentaaliga lausetes oleks nimetav, omastav, alalütlev või mõni muu kääne agendifunktsiooni väljendamiseks sama hea: „Kes ôlle toond kelnerin laseb endale klaasi täis valada....” (76) = ... kelneril ...; „Ta oleks lasknud end sinna Saksa kommunistiden kutsuda ...." (108) = ... Saksa kommunistidel kutsuda ...; „... haridusministeeriumin enesen algatet ópikoil....” $(141)=$... haridusministeeriumi enese ...; „... mõned minun kirjutet või tõlgit raamatud...." (432) = minu kirjutatud; „... minun algatet ja eedet rohkeid uuendeid....” $(468)=\ldots$ minu algatatud...; „... ilma laskmata end millengi häirida....” (45) = ...laskmata end millestki häirida ...; „... poogen nagu magneedin semmatuna liibub keelte külge...." $(71)=$...nagu magneedist tõmmatuna ...

Agentaaliga lause on sageli umbisikuline, ent umbisikulisust kui markeeritud kategoriaalset vormi on raskem analüüsida kui isikulist. Aaviku laused „... sellast eedet pole Saksamaan tehtud....” (25); „Selle teostamist peaks.... koordineeritama sellekohasen eriasutusen.” (27); „...kui sellane kool oleks asutet.... kellengi rikkan mehen ....” (191); „Viimane hirmus hoop anti meile venelasin ...” 
(247) oleksid lihtsamad isikulises tegumoes: ... sellast eedet pole Saksamaa teinud; ... peaks koordineerima ... sellekohane eriasutus; ... kui sellise kooli oleks asutanud ... keegi rikas mees; Viimase hirmsa hoobi andsid meile venelased. Umbisikulisus pole neis lauseis loomulik, vaid grammatiline transformatsioon, mis tuleneb üksnes soovist väljendada tegijat $n$-agentaali abil.

Mõnikord võimaldaks agentaal tõepoolest kompaktsemat väljendumist: „Sääl ei olnud ka seda rääderdamist ['kiusamist'] kaasõpilasin.” (206); „... poeg Vambola kasvateti yles sugulasin...." (486). Kuid Aavik kasutab vahel ka ise agentaalita konstruktsiooni omastav + poolt: „... vabatahtliko osavõtmisega õpilaste poolt...." (360; järjekindel keeleuuendus ütleks: ôpilasin).

Ükski keel ei saa endale lubada luksust, et iga tähendusfunktsiooni jaoks kujundataks oma grammatiline vorm. Ka ungari keele 28 käändest ning subjektiivsest ja objektiivsest konjugatsioonist ei piisa selleks.

Aavik oli valmis agentaalile andma lisafunktsioone, väites et „Kaks musta täkku.... von seltener Schönheit....” ei sobi eesti keeles ütelda seesütlevaga, küll aga agentaali abil: „Kaks täkku haruldasen kenadusen” (494). Et keeleuuenduse aegadel kasutati ka lõunaeestilist $n$-lõpulist seesütlevat, siis oleks selle sõnaühendi grammatiline tõlgendus seesütlevana ainuloomulik, seda enam, et mingit tegijafunktsiooni siin pole: „Kaks haruldases kenaduses täkku”.

Agentaali vormilist kokkulangemist lõunaeesti seesütlevaga (vt näidet „...peaks ...koordineeritama sellekohasen eriasutusen”) pidas Aavik tühiasjaks, sest ta taunis väljasuremisele kogu lõunaeesti keele.

\section{no-genitiiv}

Aaviku mõtteks oli no-genitiiviga luua eesti keelde võimalus vältida omastavakujulisi nimisõnalisi täiendeid põhisõna ees - no peab järgnevale, vormiliselt nominatiivis olevale sõnale andma genitiivi funktsiooni: venna raamat $>$ raamat no vend. Eeskujuks olid indoeuroopa keeled, kus põhisõna tihti eelneb nimisõnalisele täiendile (vn книга брата, sks das Buch meines Bruders).

Eesti keele morfoloogia ja süntaksi tüpoloogia ei anna no-genitiivile mingit šanssi. Viguri pärast (vrd laste bi-keelt) võiks seda keelemängus kasutada, kui osataks järgida Aaviku mudelit. „Ideepes” trükitud no-genitiiviga lausete põhjal otsustades ei õnnestu see tihti Aavikul endalgi. Igatahes vastuoludeta lauseanalüüs paljudes no-lausetes välja ei tule. Ei või ka olla kindel, et Aaviku päeviku ümberkirjutajad on tema konstruktsioonist alati aru saanud ja no-laused õigesti edasi andnud.

Lause „... hakkasin tõlkima no Turgenevi novellide valimik.... ” (8) on keeleuuendusliku grammatika seisukohalt vigane: ainus nimetavas käändes sõna on valimik, see aga on sihitis (tõlkima mida?); no peab andma genitiivi funktsiooni talle järgnevale nimetavas käändes nimisõnale, seega oleks Aaviku järgi õige ... hakkasin tôlkima valimikko no novellid no Turgenev.

Paljas no lisamine ei tee lauset keeleuuenduslikuks: „... mu tõlkes no Turgenevi novellide teises valimik-kogulmas ei ole häid eestikeelseid vasteid...." (350); „...kaalusin võimalust tõlkida no Huysmans'i „A rebours”” (61). Jäetagu no ära ja kõik on arusaadav, nagu sama mudeliga lauses ilma segava no-ta: „Mul on olnud kavatsus tõlkida ka valimik Maupassant'i novelle....” (62). 
no-lauseid on raske analüüsida, isegi kui tundub, et no on Aaviku (mitte eriti detailse) reegliga määratud kohas. „... olen seda katsond teha oma parandet väljaandes no „Kalevipoja” Sissejuhatus ja I lugu” (269); „Silmi avavalt mõjus minule ja Grünthalile ka lugemine no Grenzsteini raamat „Herrenkirche oder Volkskirche”..." (454). Sama lausesisu traditsioonilisse väljendusse transformeerituna polekski kohmakam: ... olen seda katsond teha oma „Kalevipoja” Sissejuhatuse ja I loo parandet väljaandes; ...Grenzsteini raamatu „Herrenkirche oder Volkskirche” lugemine ...

Järjestikuseid no-genitiive on veel raskem analüüsida: ,... viimistlemine no mu redigeering no Kreutzwaldi muinasjutukogulm...." (597) = minu Kreutzwaldi muinasjutukogulma redigeeringu viimistlemine... Ei saa eitada, et järjestikused genitiivid (minu Kreutzwaldi muinasjutukogulma redigeeringu) pole eriti elegantsed, ja kui selline rida läheb pikaks, siis kerkib ka reaalajas analüüsitavuse küsimus. Aga järjekindla no-genitiiviga poleks lugu parem. Keeles on valdkondi, kus otseteed ideaallahenduseks pole.

Esteetilisest vaatekohast võib küsida, kas lause "See oli isa no see Edith...." (532) on ilusam kui „See oli selle Edithi isa..."

no-genitiiv on algusest lõpuni läbikukkunud projekt.

\section{Käänamistüüp õnneto : õnnetoma : õnnetond}

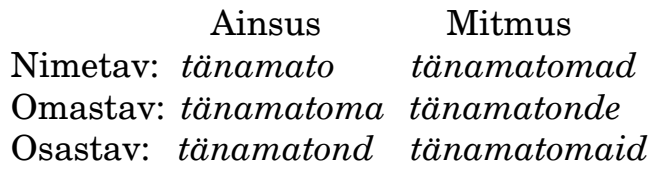

Kas on lihtne? Kas keskvõrded erapooletomam (234) ja ootamatomam (682) on lihtsad? Kas erapooletomama ja ootamatomama kõlab kaunilt ja on kooskõlas põhimõttega, mis teisal seletab, kui inetu on ühetaoliste silpide kordumine? Aavik on eesti keelt lühisilpide rohkuse pärast nimetanud mulisevaks keeleks (506) ning tema enda arvates oli tal sihiks vähendada lühisilpide lähedast järgnemist (522). Aga siin?

Põhiprobleem on siiski grammatiline tähendus: kui ootamatuma ja tänamatuma on keskvõrde tähendusega, siis on vastutustundetu fanatism hakata nõudma, et keskvõrre tähendaks algvõrret. Ja ainult selle tõttu, et Aavik soovib nii, sest nii on arhailine ja soomepärane.

Aavik teeb asja veel ettearvamatumaks. Essiivi vormideks on tal uskomatona (449), asustamatona (451), tundmatona (676), mitte uskomatomana, asustamatomana, tundmatomana, nagu omastavast moodustatud käändevormid peaksid olema. Keskvõrde essiivid peaksid Aaviku käänamissüsteemis olema uskomatomamana ja tundmatomamana, aga ka Aavik ise ei usaldanud algvõrdegi essiivi kasutada üldreegli kohaselt. Aaviku määrsõna halastamatomamin (478) on tema grammatika seisukohalt vormiliselt algvõrre, aga seda kasutatakse määrsõna keskvõrde tähenduses. Ei ole see ka peenem, otstarbekam ega suursugusem kui halastamatumalt. Ka nelja nasaali hääldamine ühes sõnas (-matomamin) on päris raske kõnetehnika harjutus. 


\section{Erinevad mitmuse vormid ja sõnamuutmissüsteemi meelevaldsus}

Aavik eelistas lühikest mitmust. Juba tema ajal oli kooliski õpetatavaks põhimõtteks kasutada sõnaühendites üht tüüpi mitmust, mitte erinevaid mitmuse moodustamise viise kõrvuti. Aaviku „Ideepe” trükivariandis eiratakse seda juhist, kui sõnaühendi ühes sõnas saab kasutada Aaviku reeglite kohast lühikest mitmust, teises aga mitte: huvitavi kergloetavi lugemispalade (15), saatuslikomi vigade (25), mugavi interjööride (26), teatavi viiside (70), kirjeldetavi ja jutustetavi nähtuste (558), laeni ulatuvi riidekappide (614). Stiilsed variandid oleksid laeni ulatuvate riidekappide või laeni ulatuvi riidekape.

Esitatud näidetestki selgub, et Aavik on mitmuse omastavasse juurde tekitanud mitu keeleuuenduslikku varianti: saatuslikoma : saatuslikomi (ains ja mitm om), mugava: mugavi, loetava : loetavi.

$i$-mitmuse omastava tüvele liitis Aavik ka komitatiivi käändelõpu, mida nn ametlik keel ei lubanud: kirjastajaiga (42), kehtivaiga (455), kappriiul raamatuiga (506), uulitsaiga (530, 573), tuttavaiga (591), otsustetuiga (598), kerjajaiga (635), onnetomaiga (666).

$\mathrm{Nn}$ ametliku eesti keele mitmus on nagunii küllalt tüüpiderohke: de-mitmus $(k a p p i+d e+l), i$-mitmus (raamatu $+i+l)$ ja tüvemitmus $(s \tilde{n} u+l, j a l u+l$, $k \ddot{a s} i+l$ ). Aavik püüdis laiendada tüvemitmuse (kõige erandlikuma mitmusetüübi) piirkonda reeglipärase de-mitmuse arvel.

Aavik ei lasknud enda ligidalegi mõtet, et keel on süsteem, milles arhailine ja erandlik ei saa olla valdav. Käänamist viimne : viimse : viimist (699) on ju võimalik sobitada eesti käänamissüsteemi, aga see ei esinda produktiivset tüüpi, vaid ikka ja jälle erandlikku. Erisusi leidub isegi käänamistüüpides, milles nendeks pole mingit põhjust: korter : kortri (609, 611, 673, 693), aga trahter : trahteri $(680,682)$.

Aavik soovitab kasutada ka instruktiivi, „...seda nii elegantset käänet....” (171). Aavikul endal esineb elustet instruktiivi ülimalt harva: „Naine langes lõhestet kolbi surnult maha” (673). Muidugi pole see elegantne vorm süstemaatiline kääne, vaid keele arhailistest kihtidest välja kaevatud määrsõnavormide ümbertõlgendus käändevormiks.

\section{Pärisnimelised omadussõnad}

Aaviku pärisnimelised omadussõnad (78-80), mida nn ametlikes grammatikates kaua aega nimetati käändumatuteks omadussõnadeks, on pärisnime omastavakujulised täiendid sellises funktsioonis nagu eesti kirjandus või slaavi rahvad. Soome keeles on sellistel täienditel omadussõna tuletusliide: saksalainen filosofia.

Ka uuendatud eesti keeles saaksid pärisnime kujuga täiendid Aavikult erilise tuletusliite: kas -laanne : -laanse (eestilaansel rahvaluulel, venelaansel köögil) või siis -naan : -naane : -naant (eestinaan rahvaluule, eestinaant rahvaluulet, eestinaanes rahvaluules, slaavinaanil rahvail). Soome -lainen/-läinen-liitliite eeskujul tehtud -laanne ei ole järgsilpide struktuuriga, aga -naan pandaks käänduma arhailise joon-tüübi eeskujul.

Paar päeva hiljem leiutab Aavik uue variandi: -nane : -nase ja siis kohe veel võimsama uuenduse: „Eestineen kool ei osand õpilasi panna huvituma 
eestineenast rahvaluulest.” Kõik peab olema võimalik: „... meil tuleb julgeda teha koguni kõrvalekaldumusi eestifoneetikast" (79). Õieti siis eestineenast foneetikast. Aavik toob näiteid oma leiutisest: veneneeni kombeid, juudineenad kaupmehed... Muidugi näeb Aavik ka selle leiduse kasutamisel ette suure hulga erandeid.

Veel parem on laadivahelduslik -nesk: eestinesk kirjandus : eestinesa kirjanduse : eestineska kirjandust jne. Nii geniaalne idee on Aavikule tulnud 19. mail 1949 kell 16.20 mäe veerul apteegi taga (79; seega on osa sellest vaimlisest odüsseiast hilisem vahelekirjutus Rootsis). Aavik mõtles eesti keele täiustamise peale pingeliselt ka apteegi taga mäe veerul. Hiljem lisandub selles küsimuses uusi leidusi ja ka vahetegemisi: inglise ja prantsuse ei vaja selliseid sufikseid (kuna nad on nagu omadussõnad), aga eesti, soome, aafri$k a$, juudi, muhame(e)di, itaalia, jaapani jne vajavad (78-80).

Selline on lõpmatuseni tõmmatud keeleuuenduse kurv. Keeleteadusega ega isegi keelekorraldusega ei ole sellel küll vähimatki puutepunkti.

\section{Keeleuuenduse õppetunnid}

Eesti kirjakeele arenguloo ülevaadetes on ammuseks tavaks vastandada Johannes Aaviku keeleuuendust ja Johannes Voldemar Veski juhitud keelekorralduslikku suunda, mis suurel määral tegeles tollal (1910-1930) ülimalt vajalike erialaterminoloogiate loomisega. Ei Aavikut ega Veskit saa pidada keeleteadlasteks. Veski laiendas keeles olemasolevaid tuletussüsteeme (tihti üle mõistlike piiride), Aaviku tegevus aga on loov leiutamine, keelemasina täiendamine ja ehtimine ilustustega, mis vahel parandavad, vahel häirivad masina tööd.

Aaviku ja Veski kõrval oli ja on eesti keelekorralduses ka tõsikeeleteaduslik suund, mis on ülekohtuselt jäänud Aaviku kärarikka keeleuuenduspropaganda ning Veski massiivse terminoloogia- ja sõnaraamatutöö varju. Teaduslikke vaateid keelekorraldusele esindasid Andrus Saareste ja Valter Tauli, ka Elmar Muuk lähenes sellele suunale. Primitiviseeritud müüt Aaviku ja Veski vastandlikest suundadest on kahjuks elujõuline ka tänapäeval.

Andrus Saareste tagantjärelehinnang Aaviku keeleuuendusele on õiglane ja heatahtlik: „Aaviku enda hea, ladus, nõtke ja rütmiline keel ja stiil ongi olnud uuendusliikumise peamiseks soodustajaks ja tema mõju teguriks, igatahes suuremal määral kui tema teooria ja põhjendused. Kalduks isegi uskuma, et tema keel ilma uuendusteta on sama hea kui koos nendega, kui viimaks mitte paremgi. Tema osavus keelt käsitleda vabandab isegi uuendusi” (Saareste 1951: 56).

Õhku jääb küsimus Aaviku enda suulisest keelest. Aavik ise vist ei kõnelnud kuigi uuenduslikku keelt. Äärmuslik keeleuuendus jäi sisekõneks, mida ta ei kasutanud ka oma ilukirjanduse tõlgetes.

Torontos Orto kirjastusel 1954. aastal ilmunud Mika Waltari „Sinuhe” eestikeelse tõlke kohta ütleb Waltari uurija Panu Rajala, et Aaviku tõlget peetakse kauniks, maneerlikuks ja vananenuks (Rajala 2008: 508). Ka Aaviku tõlgitud Waltari „Turms Surematu” (Waltari 1959) ei näita erilist uuenduslikkust: selles leidub mõningaid põhjendatud kunstsõnu, keeleuuenduslikku stiili lauseehituses ning näpuotsaga grammatilist iseäratsemist. Kõik see ei 
ületa tõlkijale lubatud stiilivabaduste piire, liialdusi pole (võimalik muidugi, et kirjastaja survel).

Aaviku usk keele kiirkorras ja meelevaldse ümbertegemise võimalikkusse on kahjuks vastavuses Eesti ühiskonna suure osa mentaliteediga, milleks on pigem usk furoorimeestesse, selgeltnägijatesse ja imearstidesse kui teadlastesse, pigem kiire rikkaks saamine aferistlike projektide kui töö abil. Selline suhtumine ei asenda teadlasi ja teaduslikku maailmavaadet. Ka Aaviku „teooria” ei asenda teaduslikku keelekorraldust.

Keeleuuendus oli edukas ainult nendes raamides, mis keele struktuurina oli ette antud. Rohkemat saaks taotleda ainult surve abil, ja nagu nüüd „Ideepe" põhjal teame, poleks Aavik tagasi kohkunud ka selle ees ei radikaalse keeleuuenduse sundkorras kehtestamisel ega Eesti ühiskonnaelu korraldamisel. Eesti ühiskonna õnneks niisuguseid võimalusi Aavikul polnud.

\section{Märkus toimetamistöö kohta}

Aaviku käsitsikirja ümberkirjutamine on olnud suur töö. Vigu täielikult vältida on siin vaevalt võimalik.

Autentsuse huvides on Aaviku enda võgrad trükisesse teadlikult sisse jäetud. Aga kui kommentaarid puuduvad, siis pole Aaviku ja ümberkirjutajate vead eristatavad. Vahel siiski: rindeteates „... nad on mito kyla ajand sakslaste toetuspunktide vahele....”(297) peab arvatavasti olema „...mitu kiilu/ kiilo...", muidu on lause mõttetu.

Saksa keeles on asjatuid vigu: so wollen vir sehön spielen (322; wir schön), Vermächnis (356; Vermächtnis), unsina (358; Unsinn), ausschiessen (368; ausschließen), Niederlange (368; Niederlage), schüchter (372; schüchtern), beflanzen (712; bepflanzen); poitma : poidan 'ära ostma (altkäemakuga)' saksa vasteks on antud beobachten, peaks nähtavasti olema bestechen (370). Selliste küsitavuste puhul oleksid Helgi Vihma ja Aili Norberg võinud paluda abi teistelt keeleinimestelt.

Suur töö on tehtud. Vaade eesti keele maailmale muutub - võib-olla mitte just nii, nagu „Ideepe” avaldajad kavatsesid.

\section{Kirjandus}

A avik, Johannes 1919. Valik rahvalaule. Valind ja seletavate lisadega ning sõnadega varustand Johannes Aavik. Tartus: Istandik.

A a vi k, Johannes 1924. Keeleuuenduse äärmised võimalused. [Tartu:] Istandik. [Teine, muutmata trükk, Stockholm 1974.]

A a vik, Johannes 1933. 20 Euroopa keelt. [Tartu:] Istandik. [Faksiimiletrükk Tallinn: Johannes Aaviku Selts, 2005.]

H in t, Mati 2011. Kas ynned sa olbama sirnangot? Johannes Aaviku visionäärsus keeleteoreetilisest vaatepunktist. - Keel ja Kirjandus, nr 11, lk 809-820.

L a u g s te, Eduard 1948. Valimik eesti rahvalaule. Tallinn: Ilukirjandus ja Kunst.

R a j a l a, Panu 2008. Unio mystica. Mika Waltarin elämä ja teokset. Helsinki: Werner Söderström Osakeyhtiö. 
S a a r e s te, Andrus 1951. Üksiku ja üldsuse osast keeleelus. Johannes Aaviku elutöö puhul. - Pühendusteos Johannes Aavikule 70. sünnipäeva puhul 8. detsembril 1950. Lund, lk 47-57.

$\mathrm{S}$ a h k a i, Heete 2011. Eesti genitiivse agendifraasi süntaks. - Keel ja Kirjandus, nr 1, lk 12-30.

Ta u li, Valter 1982a. Keeleuuenduse tulemused ja tähtsus. - Tulimuld, nr 2, lk 87-96.

T a u li,Valter 1982b. Johannes Aaviku keeleuuendus. Kriitiline ülevaade. Stockholm.

W a lt a r i, Mika 1959. Turms Surematu. I-II kd. Soome keelest tõlkinud Johannes Aavik. Toronto: Orto.

\section{Radical Language Renewal of Late Johannes Aavik}

Keywords: revaluation of „language renewal”, artificial words, phonotactics, invented grammar, typology, diary „Ideepe” of Johannes Aavik, Estonian

Without doubt, Johannes Aavik (1880-1973) is one of the most popular and widely known personalities in Estonian linguistics. His activity in the 1910-20s was focused on a renewal of literary Estonian, aimed at enriching its vocabulary and grammar. For this purpose he borrowed words from Estonian dialects and from Finnish, but his most famous achievements are concerned with coining new stems. His idea was to provide Estonian with new invented words enabling translation of any nuance of the words or expressions used in the most cultivated languages.

Although Aavik is a disputed personality, only very few researchers have dared to ask whether this is in principle a good idea, especially if carried out without a consistent theoretical framework, to restructure the meanings in one language just to match those in some other languages?

Aavik wished, for example, to alter the phonetic structure of everyday Estonian vocabulary by promoting archaization of the phonetic shape of many words, e.g. by substituting $o$ for $u$ in the non-initial syllables in an arbitrarily selected vocabulary (kalju > kaljo 'rock', kirjutama > kirjotama 'to write') consisting of about 700 words in all. In fact, this would have been a reversal of a historical sound law, which is as impossible as a reversal of time.

Having studied historical linguistics Aavik had an understanding of the importance of phonetic homogeneity in the vocabulary, but in his own inventions he very often neglected the phonetic and phonotactic rules of Estonian word forms. In many cases he tried to introduce in literary Estonian either archaic or alien (Finnish) syllable structures.

In the field of grammar his intentions were even more ambitious: he wished to provide Estonian grammar with certain forms and constructions he admired in Latin, Russian, Finnish, or even Arabic. In those invented grammatical forms he most often ignored the phonotactic constraints of Estonian, and in some cases even language typology. E.g., Estonian has one gerundive form (-des), but Aavik wanted to introduce three more gerundial forms (independent participles) in order to build a symmetrical set of active and passive, present and past gerundives (some of them with complicated morphophonological variants and a dubious pronunciation). 
Whenever possible Aavik preferred complicated grammatical rules, considering archaic morphology and morphophonology less banal than regular declension and conjugation.

Also, Aavik invented some fully new cases to be added to the 14-case system of Estonian (i.e. agental, relative, and a typologically alien prepositional no-genitive).

In 2010 the war-time (1942-1943) diary „Ideepe” by Aavik was first published. In that text, comprising 700 pages, Aavik feels free to practise language renewal without limits. After reading that text one should certainly be thankful to Aavik for his many initiatives, yet even more thankful to history for not enabling Aavik to enforce his most radical ideas upon the whole nation and their language.

Mati Hint (b. 1937), Professor Emeritus of Tallinn University 